Finanse, Rynki Finansowe, Ubezpieczenia nr 3/2017 (87), cz. 1

\title{
Analiza ryzyka w opracowaniu planu audytu na przykładzie Miejskiego Ośrodka Pomocy Społecznej
}

\author{
Izabela Emerling*
}

\begin{abstract}
Streszczenie: $\mathrm{Cel}$ - W ostatnich latach duże znaczenie przywiązuje się do audytu jako bardzo ważnego instrumentu ochrony przed wszelkiego rodzaju ryzykiem. Celem artykułu jest przedstawienie $i$ analiza teoretycznych oraz praktycznych aspektów dotyczących audytu i ocena ryzyka audytu na przykładzie Miejskiego Ośrodka Pomocy Społecznej.

Metodologia badania - Zastosowane metody badawcze oparte są na studiach literaturowych z badanego zakresu oraz analizie oceny ryzyka przeprowadzonego przez MOPS i wytyczeniu zadań audytu.

Wynik - Artykuł zawiera listę przebadanych różnych rodzajów ryzyka na przykładzie Miejskiego Ośrodka Pomocy Społecznej w Katowicach oraz uzasadnienie podjętych działań w celu uniknięcia ryzyka.

Oryginalność/wartość - Artykuł jest oryginalny, gdyż zastosowano metody badawcze charakterystyczne dla konkretnej jednostki.
\end{abstract}

Słowa kluczowe: jednostka finansów publicznych, ryzyko, ochrona, identyfikacja ryzyka, audyt finansowy

\section{Wprowadzenie}

Koncepcja współczesnego audytu wewnętrznego zaczęła formować się w XX wieku w Stanach Zjednoczonych, w 1941 roku kiedy powstało międzynarodowe stowarzyszenie Instytut Audytorów Wewnętrznych (IIA) (Bożek, Emerling, 2016, s. 487). Wzmożone wysiłki instytutu rozszerzyły granice audytu, który obecnie obejmuje badanie działalności instytucji oraz jej kierownictwa (Winiarska, 2008, s. 12). Misją Instytutu Audytorów Wewnętrznych jest: „Być czołowym międzynarodowym stowarzyszeniem zawodowym działającym na całym świecie w celu promowania i rozwoju praktyki audytu wewnętrznego" (Brudlak, Kłopotek, 2008, s. 81).

Audyt wewnętrzny w Polsce został wprowadzony do sektora finansów publicznych 1 stycznia 2002 roku (Przybylska, 2010, s. 7). Dzięki wprowadzeniu audytu wewnętrznego do sektora finansów publicznych, Polska wypełniła jedno z zobowiązań negocjacyjnych z Unią Europejską, która zobligowała wszystkie państwa kandydujące do stworzenia systemu zapewniającego efektywność wykorzystania finansowych środków publicznych, w tym

\footnotetext{
* dr Izabela Emerling, Uniwersytet Ekonomiczny w Katowicach, Wydział Finansów i Ubezpieczeń, Katedra Informatyki i Rachunkowości Międzynarodowej, e-mail: izabela.emerling@ue.katowice.pl.
} 
również środków z funduszy unijnych. Obecnie audyt wewnętrzny działa na podstawie przepisów Ustawy z dnia 27 sierpnia 2009 roku o finansach publicznych (Dz.U. 2013, poz. 885). Od 1 stycznia 2015 roku nastąpiła najnowsza zmiana, której jedną z wielu istotnych poprawek w stosunku do poprzednio obowiązującej ustawy o finansach publicznych jest wprowadzenie regulacji dotyczących zmian funkcjonowania audytu wewnętrznego w jednostkach sektora finansów publicznych oraz regulacji planowania i wykonania budżetów zadaniowych.

Celem artykułu jest analiza ryzyka ujętego w planie audytu na przykładzie Miejskiego Ośrodka Pomocy Społecznej w kontekście oceny ryzyka.

\section{Audyt wewnętrzny w jednostkach finansów publicznych}

„Audyt wewnętrzny jest niezależną, obiektywnie zapewniającą i doradczą działalnością, której celem jest dodanie wartości i usprawnienie działalności operacyjnej organizacji”" Skupiając się na drugim elemencie tej definicji należałoby zauważyć, że określenie „wewnętrzny" odnosi się do zadań wykonywanych w granicach instytucji przez własnych pracowników, a nie przez zewnętrznych rewidentów, audytorów czy inne podmioty niebędące bezpośrednio częścią danej instytucji (Moeller, 2011, s. 26). Niektóre pojęcia z definicji audytu wewnętrznego wyjaśniono w Glosariuszu do standardów.

Wraz z rosnącą rolą audytu wewnętrznego, coraz więcej innych definicji audytu tworzą organizacje zrzeszające audytorów wewnętrznych. Audyt wewnętrzny jest niezależną i obiektywną oceną sposobu, w jaki organizacja jest zarządzana i kontrolowana. Zarządzanie obejmuje przy tym głównie ochronę majątku oraz wydajne i oszczędne korzystanie z zasobów organizacji (Banaszkiewicz, 2003, s. 6).

Organem właściwym administracji rządowej do spraw audytu wewnętrznego został minister finansów, a jego zadaniem było upowszechnienie i określenie standardów audytu wewnętrznego, jego ocena, wydanie wytycznych oraz współpraca z krajowymi i zagranicznymi instytucjami zajmującymi się audytem wewnętrznym (Kostur, 2012, s. 34). Audyt wewnętrzny, zgodnie z pierwszą ustawową definicją, obejmował ogół działań, dzięki którym kierownik jednostki uzyskiwał obiektywną i niezależną ocenę funkcjonowania jednostki w zakresie gospodarki finansowej pod względem legalności, gospodarności, celowości, rzetelności, a także przejrzystości i jawności (ustawa o finansach publicznych). Przyjęto wówczas, że audyt wewnętrzny obejmuje zapisy w księgach rachunkowych oraz badanie dowodów księgowych, ocenę systemu gromadzenia środków publicznych i dysponowania nimi oraz gospodarowania mieniem, ocenę gospodarności i efektywności zarządzania finansowego (Przybylska, 2010, s. 32). Definicję audytu w polskim prawie poszerzono dopiero 5 lipca 2002 roku w Rozporządzeniu Ministra Finansów w sprawie szczegółowego sposobu i trybu przeprowadzania audytu wewnętrznego. Rozporządzenie dokładnie określa sposób i tryb przeprowadzania audytu wewnętrznego, w tym: szczegółowe warunki planowania audytu wewnętrznego oraz wzór planu audytu wewnętrznego, tryb przeprowadzania 
audytu wewnętrznego oraz sposób współpracy z pracownikami komórki, w której jest on przeprowadzany, sposób dokumentowania wyników audytu wewnętrznego, tryb sporządzania i elementy sprawozdania z przeprowadzenia audytu wewnętrznego. Rozporządzenie również uregulowało zadania audytora wewnętrznego.

\section{Planowanie audytu i ocena ryzyka}

Ciągłe zmiany, rozwój organizacyjny i technologiczny spowodowały konieczność zupełnie nowego spojrzenia na audyt. Dotychczasowy model skupiał uwagę głównie na systemach kontroli wewnętrznej jako podstawowym obszarze badania dokonywanego przez audyt wewnętrzny. Od kilkunastu lat obserwuje się jednak znaczną zmianę tej orientacji i położenie bardzo wyraźnego nacisku na ryzyko. Cały proces audytu obecnie przedstawia się w kontekście nowego postrzegania ryzyka charakteryzującego się planowaniem audytu na rok, czyli oceną ryzyka w skali makro. Ocena ta jest ściśle powiązana z różnego rodzaju ryzykiem zagrażającym osiągnięciu celów strategicznych badanej jednostki (Knedler, Stasiak, 2010, s. 21).

Ze względu na to, że w większości przypadków audytorzy nie są w stanie przebadać w ciągu roku całości jednostki, konieczne jest przyjęcie odpowiedniej metody gwarantującej dostarczenie kierownikowi badanej jednostki maksymalnie użytecznej, faktycznej i aktualnej informacji odnośnie do poprawności działania podmiotu (Grocholski, 2004, s. 13).

Audyt wewnętrzny przeprowadzany na podstawie rocznego planu audytu oparty jest na ocenie i analizie ryzyka. Plan powinien przedstawiać opis działań jakie audytor wewnętrzny chce zrealizować w ciągu roku. W szczególności powinien obejmować:

- wyniki przeprowadzonej analizy ryzyka,

- wyniki przeprowadzonej analizy zasobów osobowych,

- listę obszarów ryzyka, w których zostaną przeprowadzone zadania zapewniające,

- informacje na temat czasu planowanego w osobodniach na realizację poszczególnych zadań zapewniających, doradczych i sprawdzających,

- informacje na temat cyklu audytu (Rozporządzenie Ministra Finansów, 2010).

W Glosariuszu, opracowanym przez zespół do spraw ujednolicenia terminologii dotyczącej kontroli i audytu w administracji publicznej, ryzyko jest opisane jako „Prawdopodobieństwo, że określone zdarzenie wystąpi i niekorzystnie wpłynie na osiągnięcie danego celu" (Glosariusz, 2005, s. 34). Ocena ryzyka, istotnych błędów w obszarach, które mają zostać poddane audytowi, oparta jest na kryteriach dotyczących istotności i ryzyka. Musi ona prowadzić do wyboru tych zadań z potencjalnych zadań audytu, które są narażone na największe ryzyko. Audytor wewnętrzny przeprowadza ocenę ryzyka dotyczącego środowiska audytu i dokonuje w niej identyfikacji obszarów ryzyka oraz analizy ryzyka (Kostur, 2012, s. 175). W celu przygotowania planu audytu należy zacząć od wyznaczenia obszaru ryzyka, czyli określenia procesów, zjawisk lub problemów wymagających audytu wewnętrznego. Aby wyznaczyć ten obszar należy go dokładnie zidentyfikować. 
Identyfikację obszarów ryzyka przeprowadza audytor wewnętrzny według własnej oceny, która wynika, i w dużej mierze zależy, od wiedzy audytora o działaniach jednostki, jej strukturze, pracownikach, obowiązujących przepisach. Przy identyfikacji audytor powinien brać pod uwagę przede wszystkim: cele i zadania jednostki, przepisy prawne dotyczące działania jednostki oraz ich ewentualne zmiany, wyniki wcześniej przeprowadzonego audytu, wyniki wcześniej dokonywanych innych ocen adekwatności, efektywności i skuteczności procedur i mechanizmów w jednostce, sprawozdania finansowe oraz sprawozdania z wykonania budżetu, wyniki rozmów, jakie przeprowadził z kierownictwem, kierownikami komórek i innymi pracownikami jednostki.

Podczas identyfikacji obszarów ryzyka można kierować się różnymi kryteriami, np. rodzajem działalności prowadzonej przez jednostkę czy strukturą organizacyjną. Identyfikując obszary ryzyka $\mathrm{w}$ jednostkach sektora finansów publicznych, należy zawsze wziąć pod uwagę czynniki naruszające dyscyplinę publiczną (Tyka, 2005, s. 21).

Bardzo ważnym źródłem informacji przy identyfikacji obszarów ryzyka dla audytora mogą okazać się pracownicy jednostki, dlatego ważne jest, aby wzbudzał on zaufanie i łatwo nawiązywał kontakty z innymi. Powinien uważnie słuchać nie narzucając swoich wniosków, ale również oceniać dość krytycznie uzyskane informacje, ponieważ w niektórych sytuacjach pracownicy mogą celowo ukrywać istotne zagrożenia w celu uniknięcia badania audytowego (Kostur, 2012, s. 176).

Dokonując analizy ryzyka, audytor musi zwracać uwagę na newralgiczne, wrażliwe punkty związane z działalnością jednostki.

Metody jakimi audytor może się posłużyć identyfikując obszary ryzyka przedstawiono na rysunku 1.

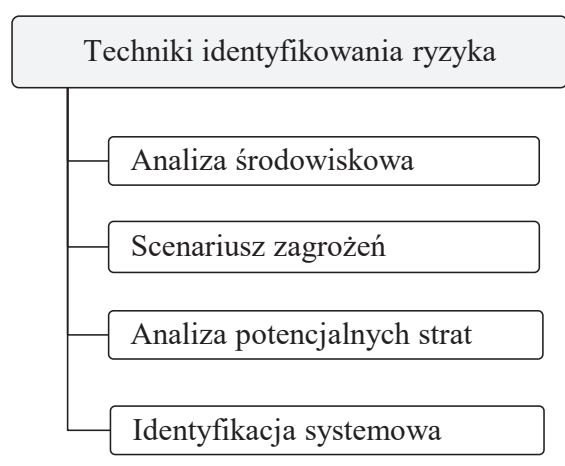

Rysunek 1. Techniki identyfikowania ryzyka

Źródło: opracowanie własne na podstawie Czerwiński (2005), s. 81-82.

W analizie środowiskowej ryzyko oceniane jest z perspektywy zmian środowiska zewnętrznego oraz wpływu tych zmian na proces zarządzania i kontroli. Scenariusz zagrożeń 
to głównie przewidywanie, w jaki sposób system wewnętrznej kontroli może zostać pominięty przez oszustwo lub nieszczęśliwy wypadek. W analizie potencjalnych strat, ryzyko analizowane jest z perspektywy zasobów fizycznych, finansowych, ludzkich oraz niematerialnych organizacji. Identyfikacja systemowa jest oceną wpływów wszystkich czynników ryzyka, które są możliwe do zidentyfikowania (Czerwiński, 2005, s. 81-82).

Usprawnieniu procesu szacowania ryzyka oraz ustalenia hierarchii obszarów ryzyka według poziomu ryzyka służy prawidłowe opracowanie czynników ryzyka, czyli cech charakterystycznych dla danego procesu, które wskazują na możliwość wystąpienia zdarzenia mogącego niekorzystnie wpłynąć na osiągnięcia określonego celu (Glosariusz, 2005, s. 11). W literaturze istnieją liczne klasyfikacje czynników ryzyka, jednak najczęściej spotykany podział przedstawiono na rysunku 2 .

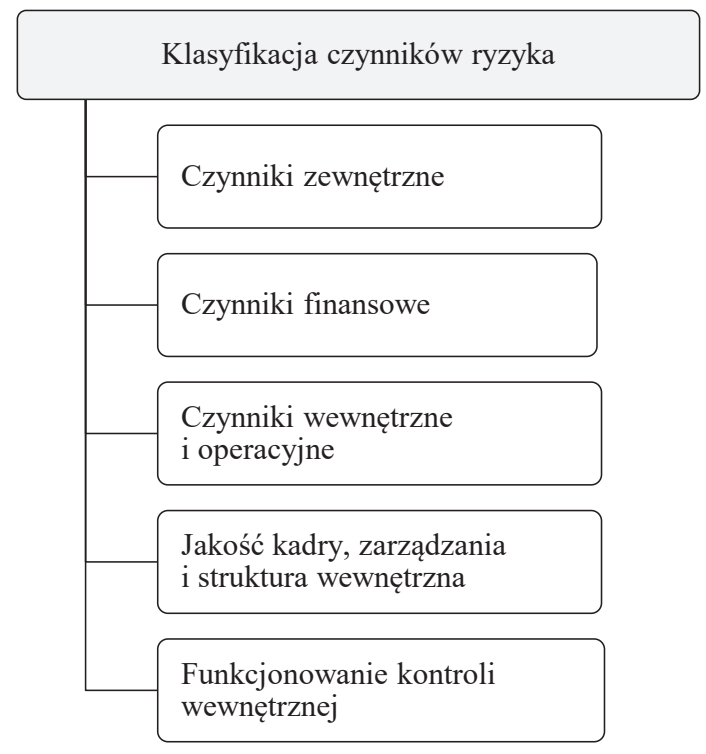

Rysunek 2. Klasyfikacja czynników ryzyka

Źródło: opracowanie własne na podstawie Czerwiński (2005), s. 83-85.

Analiza ryzyka (Czerwiński, Grocholski, 2003, s. 56):

- umożliwia wyliczenie i monitorowanie ryzyka niepowodzenia w audycie projektów,

- pomaga ocenić adekwatność i skuteczność systemu kontroli wewnętrznej,

- pozwala wycenić poszczególne elementy systemu kontroli wewnętrznej,

- pozwala ocenić, jak jednostka zarządza ryzykiem.

Analiza ryzyka obejmuje wiele niezbędnych, następujących po sobie etapów zaprezentowanych na rysunku 3 . 


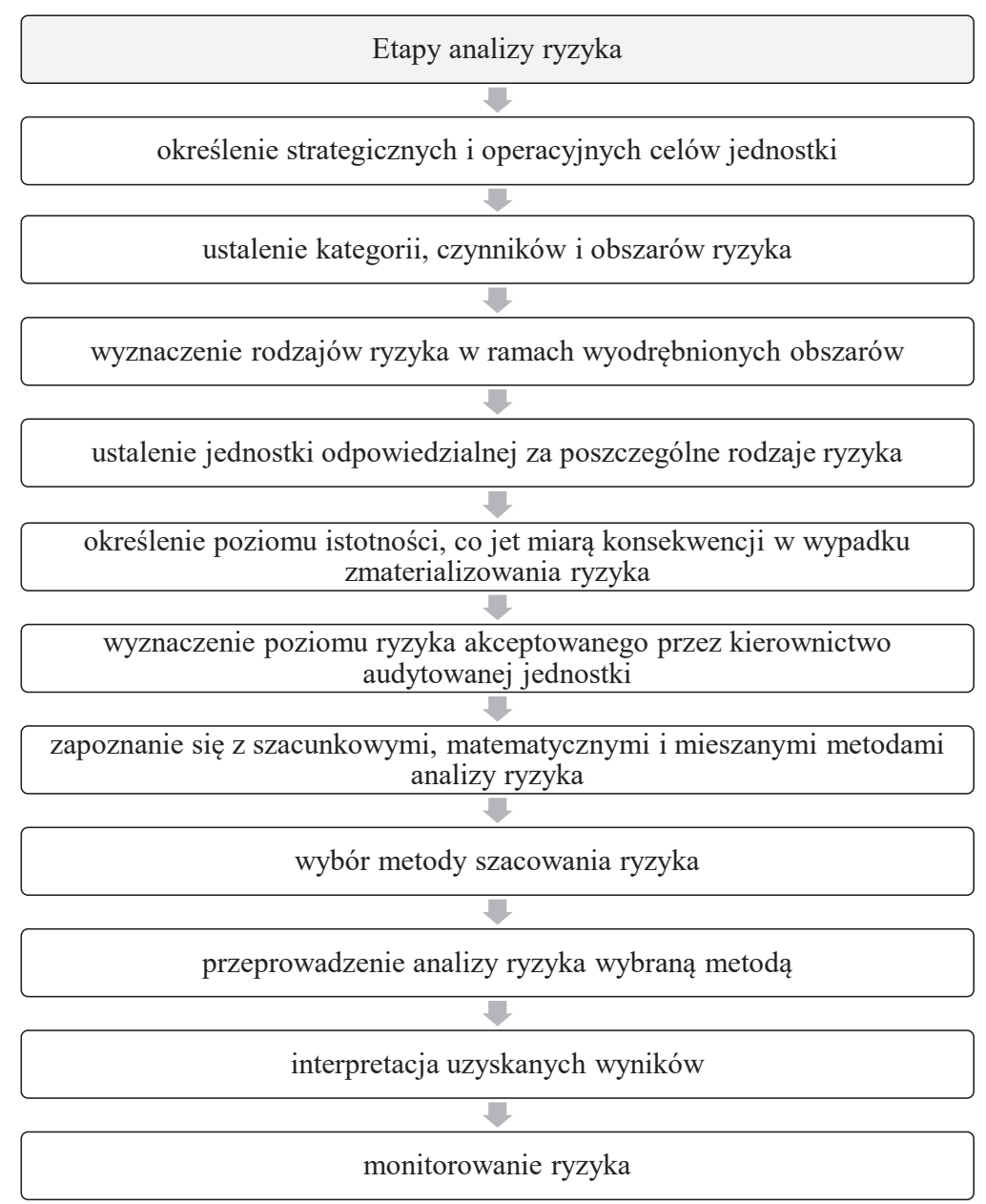

Rysunek 3. Etapy analizy ryzyka

Źródło: opracowanie własne na podstawie Kiziukiewicz (2007), s. 90-91.

\section{Organizacja audytu i ocena ryzyka w MOPS}

Audyt wewnętrzny jest działalnością niezależną i obiektywną, której celem jest wspieranie Dyrektora Miejskiego Ośrodka Pomocy Społecznej w realizacji celów i zadań przez systematyczną ocenę kontroli zarządczej oraz czynności doradcze. Ocena ta dotyczy w szczególności adekwatności, skuteczności i efektywności kontroli zarządczej. Kierownik komórki audytu wewnętrznego, albo audytor usługodawcy, w celu przygotowania planu audytu przeprowadza w sposób udokumentowany analizę ryzyka (Rozporządzenie Ministra Finansów, 
2010). Analizę ryzyka rozpoczęto od wykonania oceny potrzeb audytu, czyli identyfikacji obszarów ryzyka, w obrębie których realizowane będą zadania audytowe.

Wyodrębniono 17 obszarów ryzyka w działalności MOPS, które umieszczono w kolumnie 1 tabeli 5. Następnie określono kategorie ryzyka, opisano je i przyporządkowano im określone wagi co przedstawiono w tabeli 1.

\section{Tabela 1}

Opisane kategorie ryzyka z przyporządkowanymi im określonymi wagami

\begin{tabular}{|c|c|c|c|}
\hline Kategoria ryzyka & Waga ryzyka (\%) & Ocena & Opis \\
\hline \multirow{4}{*}{ Istotność } & \multirow{4}{*}{25} & 1 & brak implikacji finansowych \\
\hline & & 2 & małe implikacje finansowe \\
\hline & & 3 & duże implikacje finansowe \\
\hline & & 4 & kluczowy system finansowy \\
\hline \multirow{4}{*}{ Jakość zarządzania } & \multirow{4}{*}{15} & 1 & bardzo wysoka \\
\hline & & 2 & wysoka \\
\hline & & 3 & umiarkowana \\
\hline & & 4 & niska \\
\hline \multirow{4}{*}{ Kontrola wewnętrzna } & \multirow{4}{*}{25} & 1 & bardzo wysoka \\
\hline & & 2 & wysoka \\
\hline & & 3 & zadawalająca \\
\hline & & 4 & niska \\
\hline \multirow{4}{*}{ Wpływ czynników zewnętrznych } & \multirow{4}{*}{15} & 1 & niski \\
\hline & & 2 & umiarkowany \\
\hline & & 3 & wysoki \\
\hline & & 4 & bardzo wysoki \\
\hline \multirow{4}{*}{ Ryzyko operacyjne } & \multirow{4}{*}{20} & 1 & małe \\
\hline & & 2 & średnie \\
\hline & & 3 & duże \\
\hline & & 4 & bardzo duże \\
\hline
\end{tabular}

Źródło: opracowanie własne na podstawie analizy ryzyka do planu audytu wewnętrznego na rok 2016 Miejskiego Ośrodka Pomocy Społecznej.

Każdy obszar ryzyka został oceniony w każdej kategorii w skali od 1 do 4. Ocena została wykonana na podstawie profesjonalnego osądu audytora (tab. 5, kolumna 2-6). Przydzielone poszczególnym zadaniom oceny zostały umieszczone w kolumnie 9 , tabeli 5, które to wielkości skorygowano o wartość wag czynnika czasu zgodnie z tabelą 2, tj. okresu, jaki upłynął od ostatniego audytu lub kontroli (okres ten określono na podstawie danych z dokumentów wewnętrznych MOPS, tj. „Planu kontroli wewnętrznej” oraz „Planu audytu wewnętrznego") i umieszczono w kolumnie 10, tabeli 5. 


\section{Tabela 2}

Okres, jaki upłynął od ostatniego audytu

\begin{tabular}{lllll}
\hline $\begin{array}{l}\text { Okres, jaki upłynął od ostatniego } \\
\text { audytu }\end{array}$ & $\begin{array}{l}\text { Poprzedni, } \\
\text { bieżący rok }\end{array}$ & $\begin{array}{l}\text { 2 lata } \\
\text { wcześniej }\end{array}$ & $\begin{array}{l}3 \text { lata } \\
\text { wcześniej }\end{array}$ & $\begin{array}{l}\text { Wcześniej } \\
\text { lub nigdy }\end{array}$ \\
\hline Przyznana waga & 0 & 0,1 & 0,2 & 0,3 \\
\hline
\end{tabular}

Źródło: opracowanie własne na podstawie analizy ryzyka do planu audytu wewnętrznego na rok 2016 Miejskiego Ośrodka Pomocy Społecznej.

Umieszczone w kolumnie 10, tabeli 5 wielkości skorygowano o wartości wag priorytetu Dyrektora MOPS z kolumny 7 i umieszczono je w kolumnie 11 tabeli 5.

Wagi priorytetu Dyrektora określono w tabeli 3.

\section{Tabela 3}

Wagi priorytetu dyrektora

\begin{tabular}{ll}
\hline Priorytet dyrektora & Waga \\
\hline Bardzo duży & 0,35 \\
Duży & 0,30 \\
Średni & 0,20 \\
Niski & 0,10 \\
\hline
\end{tabular}

Źródło: opracowanie własne na podstawie analizy ryzyka do Planu Audytu wewnętrznego na rok 2016 Miejskiego Ośrodka Pomocy Społecznej.

Wyniki obliczeń, czyli końcową ocenę ryzyka w \% umieszczono w kolumnie 12, tabeli 5, co pozwala przyporządkować, zgodnie z kryteriami określonymi w tabeli 4, poszczególnym zadaniom audytowym odpowiednią liczbę dni roboczych potrzebnych do przeprowadzenia audytu, co następnie przedstawiono w kolumnie 13 tabeli 5.

\section{Tabela 4}

Liczba dni roboczych potrzebnych do przeprowadzenia audytu na podstawie końcowej oceny ryzyka

\begin{tabular}{ll}
\hline Końcowa ocena ryzyka (\%) & Liczba dni roboczych \\
\hline Mniej niż 30 & 20 \\
30 do 50 & 30 \\
50 do 75 & 45 \\
75 do 100 & 60 \\
\hline
\end{tabular}

Źródło: opracowanie własne na podstawie analizy ryzyka do Planu Audytu wewnętrznego na rok 2016 Miejskiego Ośrodka Pomocy Społecznej.

Poziom ryzyka każdego obszaru oszacowano według następującej zasady:

- wyniki oceny ryzyka $w$ granicach 0 do $45 \%$ - poziom ryzyka niski, 
- wyniki oceny ryzyka w granicach 45 do $65 \%$ - poziom ryzyka średni,

- wyniki oceny ryzyka w granicach 65 do $100 \%$ - poziom ryzyka wysoki.

\section{Tabela 5}

Analiza ryzyka do Planu Audytu Wewnętrznego na rok 2016 Miejskiego Ośrodka Pomocy Społecznej

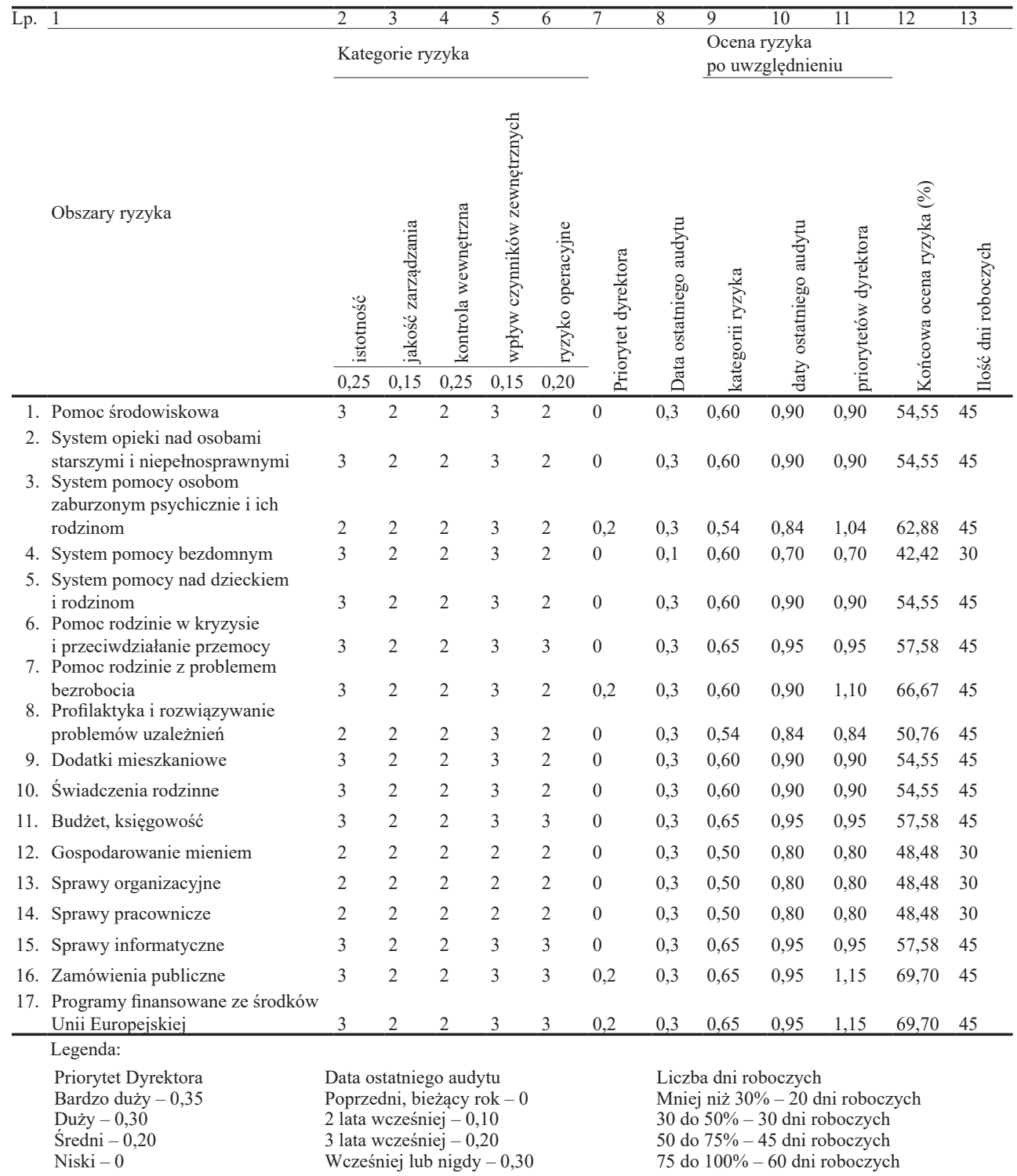

Źródło: opracowanie własne na podstawie załącznika 1 z Podręcznika audytu wewnętrznego... (2003), http:// www.ujk.edu.pl/strony/Malgorzata.Garstka/podrecznik_audytu_wewnetrznego_w_administracji_publicznej. pdf. 


\section{Wyniki przeprowadzonej analizy ryzyka w MOPS}

W wyniku przeprowadzonej analizy ryzyka w MOPS skonstruowano tabelę 6, w której pokazano obszary o najwyższym ryzyku w obszarach działalności jednostki.

\section{Tabela 6}

Wyniki przeprowadzonej analizy ryzyka w obszarach działalności jednostki

\begin{tabular}{rll}
\hline Lp. & Nazwa obszaru & Poziom ryzyka \\
\hline 1. & Pomoc środowiskowa & średni \\
2. & System opieki nad osobami starszymi i niepełnosprawnymi & średni \\
3. & System pomocy osobom zaburzonym psychicznie i ich rodzinom & średni \\
4. & System pomocy bezdomnym & niski \\
5. & System opieki nad dzieckiem i rodzinom & średni \\
6. & Pomoc rodzinie w kryzysie i przeciwdziałanie przemocy & średni \\
7. & Pomoc rodzinie z problemem bezrobocia & wysoki \\
8. & Profilaktyka i rozwiązywanie problemów uzależnień & średni \\
9. & Dodatki mieszkaniowe & średni \\
10. & Świadczenia rodzinne & średni \\
11. & Budżet, księgowość & średni \\
12. & Gospodarowanie mieniem & średni \\
13. & Sprawy organizacyjne & średni \\
14. & Sprawy pracownicze & średni \\
15. & Sprawy informatyczne & średni \\
16. & Zamówienia publiczne & wysoki \\
17. & Programy finansowane ze środków Unii Europejskiej & wysoki \\
\hline
\end{tabular}

Źródło: opracowanie własne na podstawie załącznika 2 z Podręcznika audytu wewnętrznego... (2003), http://www. ujk.edu.pl/strony/Malgorzata.Garstka/podrecznik_audytu_wewnetrznego_w_administracji_publicznej.pdf.

Analiza ryzyka wykazała wysoki poziom ryzyka w 3 z 17 obszarów działalności jednostki, tj. pomoc rodzinie z problemem bezrobocia, zamówienia publiczne oraz programy finansowane ze środków Unii Europejskiej. Na tej podstawie ustalono plan audytu na bieżący rok.

\section{Tabela 7}

Obszary ryzyka, w których zostaną przeprowadzone zadania zapewniające oraz przewidywane tematy zadań zapewniających

\begin{tabular}{lllll}
\hline Lp. & $\begin{array}{l}\text { Przewidywany temat zadania } \\
\text { zapewniającego }\end{array}$ & Obszar ryzyka & $\begin{array}{l}\text { Planowany czas prze- } \\
\text { prowadzenia zadania } \\
\text { (w osobodniach) }\end{array}$ & $\begin{array}{l}\text { Ewtualna po- } \\
\text { trzeba powołania } \\
\text { rzeczoznawcy }\end{array}$ \\
\hline 1. & $\begin{array}{l}\text { Realizacja programów pomocy } \\
\text { rodzinie z problemem bezrobocia }\end{array}$ & $\begin{array}{l}\text { pomoc rodzinie z proble- } \\
\text { mem bezrobocia }\end{array}$ & nie \\
2. Zamówienia publiczne & zamówienia publiczne & 45 & nie \\
do 14 000 euro & $\begin{array}{l}\text { Realizacja programów finansowa- } \\
\text { nych ze środków unijnych }\end{array}$ & $\begin{array}{l}\text { programy realizowane ze } \\
\text { śodków Unii Europejskiej }\end{array}$ & 45 & nie \\
\hline
\end{tabular}

Źródło: opracowanie własne na podstawie załącznika 2 z Podręcznika audytu wewnętrznego... (2003), http://www. ujk.edu.pl/strony/Malgorzata.Garstka/podrecznik_audytu_wewnetrznego_w_administracji_publicznej.pdf. 
Jednym z obszarów wysokiego ryzyka okazała się pomoc rodzinie z problemem bezrobocia, co stanowi jeden z elementów miejskiej strategii rozwiązywania problemów społecznych. Celem strategicznym realizowanym przez Miejski Ośrodek Pomocy Społecznej jest zwiększenie szans na podjęcie pracy zawodowej i przeciwdziałanie negatywnym skutkom społecznym, wynikającym z bezrobocia w rodzinie. Pogłębiona indywidualna praca socjal$\mathrm{na}, \mathrm{w}$ tym w formie poradnictwa specjalistycznego oraz rozszerzana stale współpraca ze środowiskiem lokalnym i podmiotami rynku pracy, powinna być odpowiedzią na zmieniające się zapotrzebowanie osób poszukujących zatrudnienia, w szczególności korzystających z pomocy ośrodka. W celu kompleksowego wsparcia osób znajdujących się w trudnej sytuacji życiowej ośrodek powinien ściśle współpracować z takimi instytucjami rynku pracy jak: Powiatowy Urząd Pracy, Wojewódzki Urząd Pracy oraz Ochotniczy Hufiec Pracy. Na wniosek audytora zaproponowano także czynności sprawdzające. Audytor wewnętrzny może przeprowadzić również czynności sprawdzające, dokonując oceny działań jednostki audytowanej, podjętych w celu realizacji zaleceń. Takim zaleceniem objęto udzielanie dodatków mieszkaniowych. Czynności sprawdzające przedstawiono w tabeli 8.

\section{Tabela 8}

Planowane czynności sprawdzające

\begin{tabular}{llll}
\hline Lp. $\begin{array}{l}\text { Temat zadania zapewniającego, } \\
\text { którego dotyczą czynności sprawdzające }\end{array}$ & Obszar ryzyka & $\begin{array}{l}\text { Planowany czas } \\
\text { przeprowadzenia } \\
\text { czynności sprawdzających } \\
\text { (w osobodniach) }\end{array}$ \\
\hline 1. & Udzielanie dodatków mieszkaniowych & $\begin{array}{l}\text { dodatki } \\
\text { mieszkaniowe }\end{array}$ & 3 \\
\hline
\end{tabular}

Źródło: opracowanie własne na podstawie załącznika 2 z Podręcznika audytu wewnętrznego... (2003), http:// www.ujk.edu.pl/strony/Malgorzata.Garstka/podrecznik_audytu_wewnetrznego_w_administracji_publicznej. pdf.

MOPS realizuje zadanie własne gminy w zakresie przyznawania dodatków mieszkaniowych. Postępowanie administracyjne w celu przyznania dodatku mieszkaniowego podzielono na trzy etapy. Etap pierwszy - wniosek zostaje przyjęty w Dziale Poradnictwa i Informacji i tam dokonuje się wstępnej weryfikacji danych zawartych we wniosku oraz wymaganych załączników i dokumentów. Etap drugi - dokonuje się rozpatrzenia wniosku, co sprowadza się do merytorycznej oceny informacji przekazanych przez klienta oraz przeprowadza postępowanie, które zostaje zakończone wydaniem decyzji. Etap trzeci polega na realizacji wydanych decyzji administracyjnych, który odbywa się w Dziale Realizacji Świadczeń.

Kierownik komórki audytu wewnętrznego ustalił również „cykl audytu”, czyli obszary ryzyka, które powinny być objęte audytem wewnętrznym w kolejnych latach. Cykl audytu w Miejskim Ośrodku Pomocy Społecznej w Katowicach wynosi 3 lata, co przedstawiono w tabeli 9. 


\section{Tabela 9}

Cykl audytu

\begin{tabular}{llll}
\hline Lp. & Nazwa obszaru & $\begin{array}{l}\text { Planowany rok przeprowadzenia } \\
\text { audytu wewnętrznego }\end{array}$ & Uwagi \\
\hline 1. & Świadczenia rodzinne & 2017 \\
2. & Pomoc środowiskowa & 2017 \\
3. & Systemy informatyczne & 2017 \\
4. & System opieki nad osobami starszymi & \\
$\quad$ i niepełnosprawnymi & 2018 \\
5. & System pomocy osobom zaburzonym psychicznie & \\
& i ich rodzinom & 2018 \\
6. & Gospodarowanie mieniem & 2018 \\
7. & System opieki nad dzieckiem i rodzinom & 2019 \\
8. $\quad$ Pomoc rodzinie w kryzysie i przeciwdziałanie & 2019 \\
$\quad$ przemocy & 2019 \\
9. & Sprawy pracownicze & \\
\hline
\end{tabular}

Źródło: opracowanie własne na podstawie załącznika 2 z Podręcznika audytu wewnętrznego... (2003), http:// www.ujk.edu.pl/strony/Malgorzata.Garstka/podrecznik_audytu_wewnetrznego_w_administracji_publicznej. pdf.

\section{Uwagi końcowe}

Audyt jako narzędzie kontroli jest bardzo ważnym instrumentem zabezpieczającym przed wystąpieniem ryzyka. Aby eliminować ryzyko, niezbędny jest udoskonalony system kontroli i ewentualne sankcje zniechęcające do niekorzystnego działania.

Celem artykułu było przedstawienie teoretycznych i praktycznych aspektów audytu oraz analiza możliwości wystąpienia ryzyka w badanym MOPS. Cel ten został zrealizowany.

Nowoczesna rola audytu wewnętrznego polega przede wszystkim na wdrażaniu systemu zarządzania ryzykiem przez jednostkę. Audyt wewnętrzny skupiony jest na ocenie efektywności działania tego systemu oraz na możliwości wprowadzenia zmian, usprawnień. Rozpoczęcie audytu to poznanie otoczenia w jakim działa jednostka i ryzyka z nim związanego oraz jednoczesna kontrola, jak zaprojektowany jest system zarządzania ryzykiem i w jakim stopniu jest on operacyjnie efektywny.

\section{Literatura}

Bożek, S., Emerling, I. (2016). Protecting the organization against risk and the role of financial audition the example of the internal audit. Oeconomia Copernicana, 3.

Banaszkiewicz, J. (2003). Audyt wewnętrzny spojrzenie praktyczne. Warszawa: SKwP ZG COSZ.

Brdulak, J., Kłopotek, A. (2008). Zarządzanie w jednostkach sektora finansów publicznych, finansowanie działalności, audyt wewnętrzny i kontrola finansowa. Warszawa: Prace Naukowe SGH.

Czerwiński, K. (2005). Audyt wewnętrzny. Warszawa: InfoAudit.

Czerwiński, K., Grocholski, H. (2003). Podstawy audytu wewnętrznego. Szczecin: LINK.

Glosariusz terminów dotyczacych kontroli i audytu w administracji publicznej (2005). Warszawa.

Grocholski, H. (red.) (2004). Praktyczne aspekty audytu wewnętrznego. Warszawa: OMIKRON. 
Kiziukiewicz, T. (2009). Audyt wewnętrzny w jednostkach sektora finansów publicznych. Warszawa: Difin.

Knedler, K., Stasiak, M. (2010). Audyt wewnętrzny w praktyce. Audyt operacyjny i finansowy. Łódź: Polska Akademia Rachunkowości.

Kostur, A. (red.) (2012). Metody i procedury audytu wewnętrznego w jednostkach sektora finansów publicznych. Katowice: Prace Naukowe Uniwersytetu Ekonomicznego w Katowicach.

Moeller, R. (2011). Nowoczesny audyt wewnętrzny. Warszawa: Wolters Kluwer.

Podręcznik audytu wewnętrznego (2003). Warszawa: Ministerstwo Finansów. Pobrano z: http://www.ujk.edu.pl/ strony/Malgorzata.Garstka/podrecznik_audytu_wewnetrznego_w_administracji_publicznej.pdf.

Przybylska, J. (2010). Audyt wewnętrzny w sektorze publicznym. Warszawa: CeDeWu.

Rozporządzenie Ministra Finansów z dnia 4 września 2015 r. w sprawie audytu wewnętrznego oraz informacji o pracy i wynikach tego audytu (Dz.U. poz. 1480).

Szczot, J. (2012). Audyt wewnętrzny w jednostkach sektora finansów publicznych. Lublin: POLIHYMNIA.

Tyka, A. (2005). Poradnik audytora wewnętrznego jednostek sektora finansów publicznych. Gdańsk: ODDK.

Ustawa z dnia 27 sierpnia 2009 r. o finansach publicznych (t.j. Dz.U. 2016, poz. 1870 z późn. zm.).

Winiarska, K. (2008). Audyt wewnętrzny. Warszawa: Difin.

\section{THE ROLE OF AUDIT IN DETECTING RISKS ON THE EXAMPLE OF THE MUNICIPAL SOCIAL WELFARE CENTER}

Abstract: Purpose - In recent years very important is attached to audit as a very important instrument of protection against all kinds of risks. The aim of this article is to present and analyze the theoretical and practical aspects of auditing on the example of the Municipal Social Welfare Center in the context of risk assessment.

Design/methodology/approach - The applied research methods are based on the literature studies of the scope examined and the risk assessment conducted by the MOPS and the design of the audit tasks.

Findings - The article contains a list of the examined risks on the example of the Municipal Social Assistance Center in Katowice and justification of the actions taken to avoid risk.

Originality/value - The article is original because it has applied research methods specific to a particular business entity.

Keywords: public finance unit, risk, protection, risk identification, financial audit

\section{Cytowanie}

Emerling, I. (2017). Analiza ryzyka w opracowaniu planu audytu na przykładzie Miejskiego Ośrodka Pomocy Społecznej. Finanse, Rynki Finansowe, Ubezpieczenia, 3 (87/1), s. 141-153. DOI: 10.18276/frfu.2017.87/1-13. 